\title{
Semi-continuous Carotenoid Production in Bioreactor from Phaffia rhodozyma Using Agro-industrial Residues
}

\author{
Luana Gayeski $^{1(\mathbb{D})}$, Rosicler Colet ${ }^{1(\mathbb{D})}$, Letícia Urnau ${ }^{1(\mathbb{D})}$, Janaína Fernandes de Medeiros Burkert ${ }^{2}$ (D), \\ Clarice Steffens ${ }^{1}$ (D), Eunice Valduga ${ }^{1 * \text { (D) }}$ \\ 1 Department of Food Engineering, URI -Erechim Av. Sete de Setembro, 1621, Erechim, Rio Grande do Sul, Brazil, 99709- \\ 910, Brazil \\ * Correspondence: veunice@uricer.edu.br;
}

Scopus Author ID 23490413300

Received: 13.04.2020; Revised: 9.06.2020; Accepted: 12.06.2020; Published: 17.06.2020

\begin{abstract}
This work has studied the semi-continuous process for carotenoids production in the bioreactor by Phaffia rhodozyma (Y-17268) using agro-industrial residues as substrate. The kinetics process was evaluated using different cuts $(25,50$, and $75 \%)$ every $96 \mathrm{~h}$, until $288 \mathrm{~h}$, to achieve a high level of productivity in total carotenoids. In a period of $192 \mathrm{~h}$ was obtained the maximum total carotenoids concentration $(477 \mu \mathrm{g} / \mathrm{g})$ with agro-industrial residues $(100 \mathrm{~g} / \mathrm{L}$ corn maceration water, $100 \mathrm{~g} / \mathrm{L}$ crude glycerol, and $20 \mathrm{~g} / \mathrm{L}$ rice parboiling water), under the following conditions: $250 \mathrm{rpm}$ agitation rate, $1.5 \mathrm{vvm}$ aeration rate, $25^{\circ} \mathrm{C}, \mathrm{pH}$ initial 4.0 , with $50 \%$ working volume cut. It was obtained $42.51 \mu \mathrm{g} / \mathrm{L}$.h of maximum productivity on total carotenoids, $0.063 \mathrm{~g} / \mathrm{L} . \mathrm{h}$ the maximum productivity on cells, and $0.067 \mathrm{~h}^{-1}$ specific maximum growth speeds. In this way, it was possible to achieve high production of carotenoids in a semi-continuous process and is a sustainable option to obtain this colorant on an industrial scale.
\end{abstract}

Keywords: Bioreactor; substrates; glycerol; corn maceration water; rice parboiling water; productivity; agro-industrial residues.

(C) 2020 by the authors. This article is an open-access article distributed under the terms and conditions of the Creative Commons Attribution (CC BY) license (https://creativecommons.org/licenses/by/4.0/).

\section{Introduction}

Carotenoids have been widely used as additives in food and feed, nutraceuticals, and cosmetics due to biological activities [1]. The global market for carotenoids is reported to reach $\$ 1.5$ billion in 2018. It will increase to an estimated value of $\$ 2.0$ billion in 2022 [2]. The industrial demand for carotenoids such as $\beta$-carotene and astaxanthin has been growing due to the large variety of its applications in foods, cosmetics, and pharmaceutical industries. As well as their use as colorants, such compounds are vitamin A precursors (pro-vitamin A), and they have antioxidant properties, allowing the use of carotenoids in preventive cancer treatments, heart diseases, and macular degeneration related to aging $[3,4]$.

Although the demand for carotenoids is rapidly increasing, their supply is limited due to inefficient production methods [1]. Many of the structurally more complex carotenoids cannot be chemically synthesized via economically viable methods [5]. Most carotenoids are extracted from natural sources with low yields due to complicated multi-step processes and low concentrations in the raw materials, which can also be further affected by unfavorable environmental conditions [6]. Therefore, the carotenoids production via microbial provides an attractive alternative, as it does not require direct land use or the time invested in growing crops for harvest and extraction. 
That has contributed to researchers interest on discovering new sources, processes, and techniques that could be employed on the intensification of these pigments by microorganisms, considering that carotenoids obtained by chemical synthesis involve a great number of complex reactions. In contrast, these same carotenoids are naturally found in microalgae, bacteria, yeasts and fungi [7].

Alternative agro-industrial residues such as molasses, sugarcane bagasse, whey, cornmeal, corn liquor, rice parboiling water, glycerol, and others, have been used for carotenoids production [8-13] to reduce production costs.

Bioprocesses are generally applied on large scale production of natural colorants due to the high cellular density and a greater microorganism growth rate [14]. In semi-continuous fermentation, a portion of the culture is removed as output, and a fraction of a culture medium is replaced with fresh media at determinate intervals of time. This fermentation has been applied to obtain carotenoid as a simple means of approximating continuous fermentation in shake flasks. Thus, it makes the semi-continuous fermentation similar to the continuous fermentation process, once the volume is kept constant. However, the difference from the fedbatch is that the volume will increase with time. The semi-continuous fermentation showed as advantages a simplified operation and reduced bioreactor size, with extremely small feed rates in relation to continuous fermentation $[15,16]$. In this process, the feed solution with agroindustrial byproducts was fed at constant intervals while the effluent is removed discontinuously. So, some problems can be avoided by intermittent feeding of the substrate as the inhibition and catabolite repression [17].

The use of yeasts in carotenoid bioproduction by the semi-continuous system with agroindustrial byproducts is still little explored. In this sense, this work aims to study the parameters (kinetic and stoichiometric) for carotenoids bioproduction using Phaffia rhodozyma (Y-17268) in a semi-continuous system with agro-industrial residues

\section{Materials and Methods}

\subsection{Conditions of cultivation and carotenoids bioproduction.}

Phaffia rhodozyma (Y-17268) certified as GRAS (Generally Recognized as Safe) was obtained from the Bioprocess Engineering Laboratory (FURG, Brazil). The strain was maintained at $4^{\circ} \mathrm{C}$ on YMA medium (Yeast Malt Extract Agar) and supplemented with $0.2 \mathrm{~g} / \mathrm{L}$ of $\mathrm{KNO}_{3}$ (Vetec, Brazil). The medium was composed of yeast extract $(3 \mathrm{~g} / \mathrm{L})$, malt extract $(3 \mathrm{~g} / \mathrm{L})$, peptone $(5 \mathrm{~g} / \mathrm{L})$, glucose $(10 \mathrm{~g} / \mathrm{L})$, and agar $(20 \mathrm{~g} / \mathrm{L}) .100 \mathrm{~mL}$ of yeast malt extract (YM) medium was used for the inoculum preparation. A suspension of cells (10\% v/v) from the stock slants was added to a sterilized Erlenmeyer flask to obtain the inoculum. The strain was incubated for $48 \mathrm{~h}$ at $25^{\circ} \mathrm{C}, 180 \mathrm{rpm}$ (New Brunswick Edison, NJ, USA) [18].

Carotenoid bioproduction was carried out for $288 \mathrm{~h}$ in a room without illumination. A Biostat bioreactor (Braun Biotech International, Holland) was utilized for experiments with a total volume of $1 \mathrm{~L}$. During the bioproduction experiments, the temperature was controlled with a water bath (Tecnal, Brazil). The $\mathrm{pH}$ monitored using a digital $\mathrm{pH}$ meter (Digimed DMPH- 2, Brazil). 


\subsection{Agro-industrial substrates.}

The agro-industrial residues used were corn maceration water (CMW), parboiled rice water (PRW), and crude glycerol all provide and acquired from the Industrial production process. The residues were supplied frozen and stored at $-20^{\circ} \mathrm{C}$ until use. The CMW was previous chemically pre-treated, according to Valduga et al. [18] using phosphoric acid, and PRW and glycerol were used without previous treatment.

\subsection{Bioproduction in a semi-continuous process.}

Carotenoid bioproduction was performed at $25^{\circ} \mathrm{C}, \mathrm{pH}_{\text {initial }} 4.0$, with a medium composed of agro-industrial residues (100 g/L CMW, $20 \mathrm{~g} / \mathrm{L} \mathrm{PRW}$, and $100 \mathrm{~g} / \mathrm{L}$ glycerol). These conditions were based on the previous study of the group [10]. Prior to inoculation, the bioreactor and its contents ( $1 \mathrm{~L}$ of the medium bioproduction) were sterilized by autoclaving at $121^{\circ} \mathrm{C}$ for $20 \mathrm{~min} .10 \%(\mathrm{v} / \mathrm{v}$ ) of inoculum was inoculated in $1 \mathrm{~L}$ medium, and cultivated for $96 \mathrm{~h}$, aeration rate $(1.5 \mathrm{vvm})$, stirring rate $(250 \mathrm{rpm}), \mathrm{pH}_{\text {initial }} 4.0$, maintaining the temperature at $25^{\circ} \mathrm{C}$. Next, were taken 25,50 , and $75 \%$ of the working volume of the bioreactor to perform the carotenoid extraction. For the semi-continuous process, a fresh volume of sterilized medium was added to the bioreactor and cropped at the same condition of the inoculum, performing two cuts every $96 \mathrm{~h}$ of bioproduction, totalizing $288 \mathrm{~h}$. In this way, were carried out 3 cycles in the semi-continuous process. These experiments were performed in triplicate.

\subsection{Recovery and quantification.}

The extraction and quantification of total carotenoids were performed according to a previous study [10]. The cells obtained from the carotenoid production were lyophilized for $36 \mathrm{~h} .0 .05 \mathrm{~g}$ dry cells were added to the test tubes along with $2 \mathrm{~mL}$ of $\left(\mathrm{CH}_{3}\right)_{2} \mathrm{SO}$ (Quimex, Brazil). Test tubes were homogenized in a shaker (New Brunswick) at $150 \mathrm{rpm}, 35^{\circ} \mathrm{C}$, for $60 \mathrm{~min}$ for the cell disruption. The samples were extracted with $4 \mathrm{~mL}$ of $\mathrm{C}_{3} \mathrm{H}_{6} \mathrm{O}$ (Quimex, Brazil) and centrifuged (MPW-351R refrigerated Laboratory Centrifuge, Poland) 4,478 x g at $5^{\circ} \mathrm{C}$ for $10 \mathrm{~min}$. The supernatant obtained in the test tubers was separated, and the carotenoid extractions were carried out until both the solvent and cells were colorless. Following, $10 \mathrm{~mL}$ $\mathrm{NaCl}$ solution $(20 \% \mathrm{w} / \mathrm{v})$ and $10 \mathrm{~mL}$ petroleum ether were added to the samples, stirred for phase separation, and remove the $\left(\mathrm{CH}_{3}\right)_{2} \mathrm{SO}$. Then, the solution was filtered with the addition of $2 \mathrm{~g} \mathrm{Na}_{2} \mathrm{SO}_{4}$ (Merck, USA), and the supernatant phase was collected.

The absorbance was read at $448 \mathrm{~nm}$ in a UV/Vis spectrophotometer (Agilent UV-8553, USA). The concentration of total carotenoid $(\mu \mathrm{g} / \mathrm{L})$ was estimated by Davies [19] equation using an absorbance coefficient of $\mathrm{E} 1 \% 1 \mathrm{~cm}=2592$ (referent to $\beta$-carotene in petroleum ether). Also, the carotenoids were expressed in the specific production of carotenoid $(\mu \mathrm{g} / \mathrm{g})$, which characterizes the total carotenoid concentration $(\mu \mathrm{g})$ by the cell mass of dried yeast $(1 \mathrm{~L}$ of fermented medium).

\subsection{Kinetics of the carotenoid bioproduction.}

The kinetics $(\mathrm{n}=3)$ were evaluated periodically, collecting the medium every $24 \mathrm{~h}$ during $288 \mathrm{~h}$ of bioproduction. The parameters evaluated were the carotenoid production, $\mathrm{pH}$ evolution, cell mass, and substrate consumption in the medium, being the latter evaluated in terms of glycerol, total nitrogen (TN), and total organic carbon (TOC). 
The conversion factor for the substrate in the product, Yp/s ( $\mu \mathrm{g}$ carotenoids/g substrate), the substrate in the biomass, $\mathrm{Yx}_{\mathrm{X} / \mathrm{S}}$ (g cells/g substrate), and the specific carotenoid production, YP/X ( $\mu$ g carotenoids/g cells), were calculated according to Bailey and Ollis [20].

The instantaneous productivity in cells $\left(\mathrm{r}_{\mathrm{x}}\right)$ and carotenoids $\left(\mathrm{r}_{\mathrm{p}}\right)$ in a semi-continuous process at constant volume also was determined according to Bailey and Ollis [20] and Colet et al. [21]. It was taken into account the rates of microbial growth $\left(\mathrm{r}_{\mathrm{x}}\right)$, product formation $\left(\mathrm{r}_{\mathrm{p}}\right)$, and substrate consumption $\left(\mathrm{r}_{\mathrm{s}}\right)$. These rates were evaluated through the mass balance of each component at a specific time.

\subsection{Analytical methods.}

\subsubsection{Cell Mass.}

The cells obtained in the semi-continuous bioproduction process were centrifuged (MPW-351R refrigerated Laboratory Centrifuge, Poland) at $3,000 \mathrm{xg}$, at a constant temperature of $5^{\circ} \mathrm{C}$ for $10 \mathrm{~min}$. Next, were washed with distilled water several times and dried in an oven (Fanem SE-320, Brazil) at $105^{\circ} \mathrm{C}$ until a constant mass.

\subsubsection{Total Organic Carbon (TOC) and Total Nitrogen (TN).}

The TOC and TN in the medium were evaluated using the catalytic combustion method at $680^{\circ} \mathrm{C}$ and $720^{\circ} \mathrm{C}$, respectively. The analyses with infrared detection were performed on Shimadzu equipment with TOC/TN analyzer (TOC-VCSH, China). The samples were diluted in ultrapure water before reading.

\subsection{3. $\mathrm{pH}$.}

The $\mathrm{pH}$ of the medium in the semi-continuous process using agro-industrial residues was determined using a digital pH meter (Digimed DMPH-2, Brazil).

\subsubsection{Glycerol.}

The glycerol of the medium in the semi-continuous process was determined according to the standard method UNE-EN 14105 [22]. The procedure steps for the determination of glycerol concentration were described previously by Colet et al. [21].

\section{Results and Discussion}

Figures 1, 2, and 3 show the kinetic curves of total carotenoid production by $P$. rhodozyma for the semi-continuous system. It is observed that from the second cycle, the high concentration of total carotenoids $(5346 \mu \mathrm{g} / \mathrm{L})$ was obtained in the system with a cut of $50 \%$ (Figure 2) with $192 \mathrm{~h}$, when compared to bioproducts with cuts of $25(4087 \mu \mathrm{g} / \mathrm{L})$ and $75 \%$ $(4127 \mu \mathrm{g} / \mathrm{L})$. The maximum concentration of biomass obtained in each cut was higher in the process that used a cut of $50 \%(3.4$ and $9.0 \mathrm{~g} / \mathrm{L}$ for the first and second cycles) than in the process that was performed cut of $75 \%$ (3.4 and $4.9 \mathrm{~g} / \mathrm{L}$ for the first and second cycles) and $25 \%$ (3.4 and $6.9 \mathrm{~g} / \mathrm{L}$ for the first and second cycles, respectively).

According to Figure 2 (a) in a semi-continuous fermentation process with a cut of $50 \%$ every $96 \mathrm{~h}$, it is observed after the second cut, a decrease in the concentration of carotenoids up to $288 \mathrm{~h}$. Thus, it is convenient to take the semi-continuous bioproduction until 
approximately $192 \mathrm{~h}$. After this time which there is a decrease in the production of carotenoids and the production is no longer associated with cell concentration.
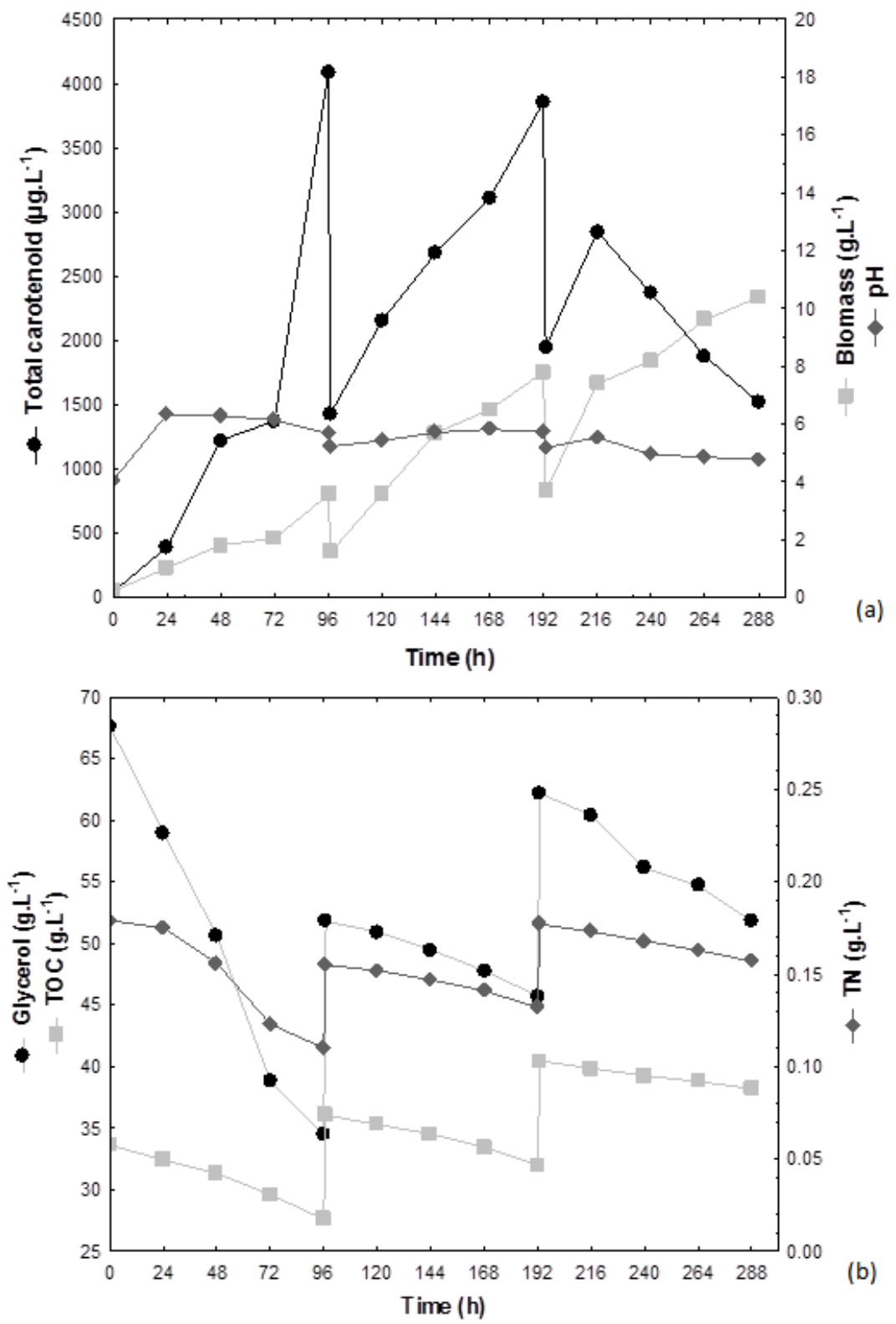

Figure 1. Kinetics of carotenoid production, biomass, and $\mathrm{pH}(\mathbf{a})$; substrates consumption: glycerol, TOC and TN (b) semi-continuous process using agro-industrial residues with a cut of 25\%, every $96 \mathrm{~h}$, until $288 \mathrm{~h}$.

Urnau et al. [9] observed in a semi-continuous bioproduction process, an increase of $\sim 55 \%$ in the total carotenoid when compared to the simple batch system, which was $2380 \mu \mathrm{g} / \mathrm{L}$. Colet et al. [21] obtained the maximum carotenoids production by $S$. salmonicolor in a semicontinuous system of $7388 \mu \mathrm{g} / \mathrm{L}$ at $288 \mathrm{~h}$, with a cut of $50 \%$, every $96 \mathrm{~h}$, using an optimized medium ( $80 \mathrm{~g} / \mathrm{L} \mathrm{CMW,} 80 \mathrm{~g} / \mathrm{L}$ glycerol and $20 \mathrm{~g} / \mathrm{L} \mathrm{RPW}$ ), showing an increase around 55\% in relation to the fed-batch process [8], and 90\% in relation to simple batch [24].

$\mathrm{pH}$ is one of the main environmental parameters that influence cell growth and product formation. In general, it increases in the first hours of fermentation (Figure 1, 2, and 3 (a)). At the beginning of the fermentation, there was an increase in $\mathrm{pH}$, possibly related to proteolysis of the microorganism. This is a natural phenomenon, which occurs after high consumption of the substrate, especially when the strain does not use another carbon source. So, result in the 
degradation of amino acids, the formation of ammonia responsible for raising the $\mathrm{pH}$. The $\mathrm{pH}$ in the agro-industrial medium decreased after the second cut, reaching the higher carotenoids production at a $\mathrm{pH}$ of 5.67 .
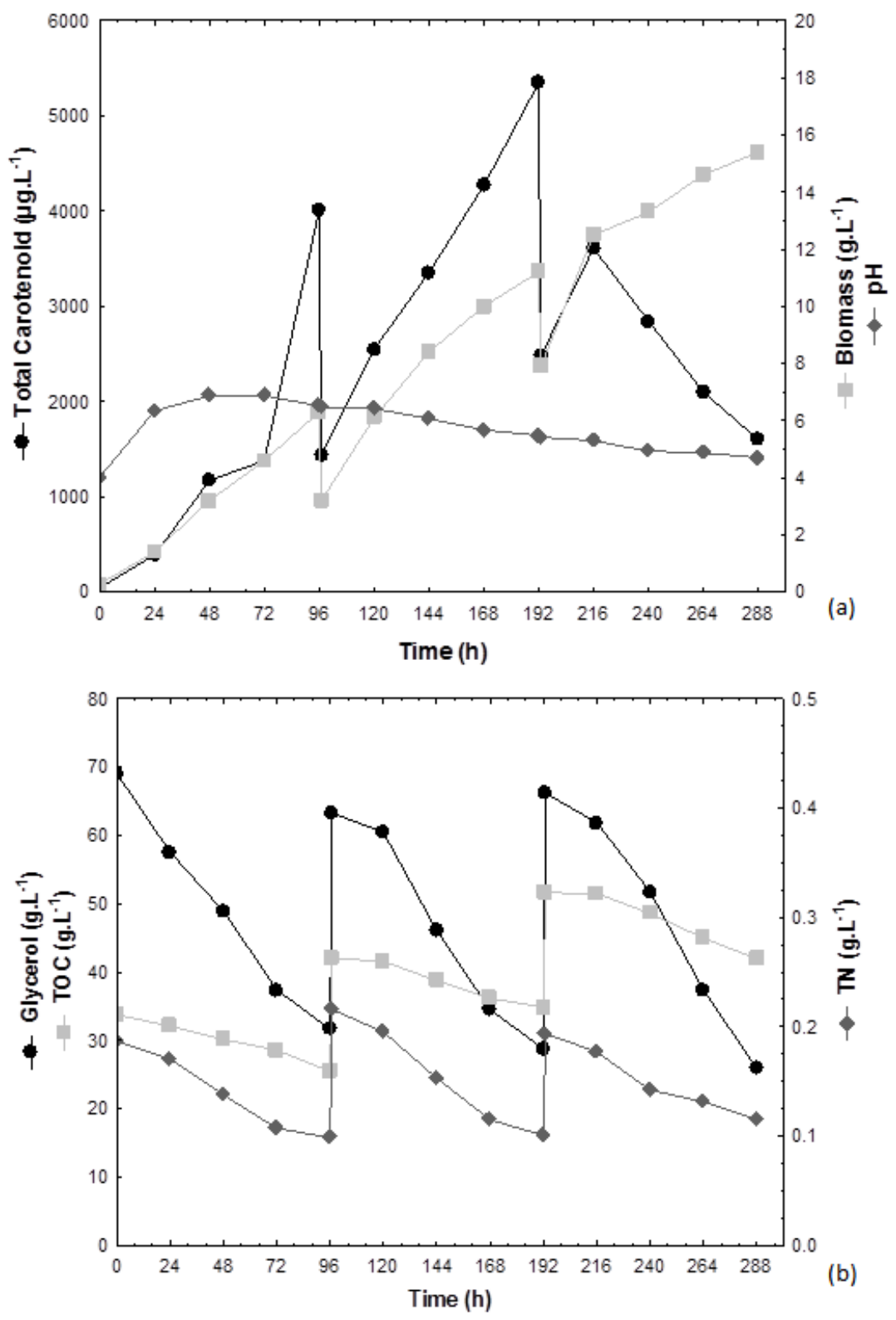

Figure 2. Kinetics of carotenoid production, biomass, and $\mathrm{pH}(\mathbf{a})$; substrates consumption: glycerol, TOC and

TN (b) semi-continuous process using agro-industrial residues with a cut of 50\%, every $96 \mathrm{~h}$, until $288 \mathrm{~h}$.

Colet et al. [21] verified the effect of $\mathrm{pH}$ on the bioreactor bioproduction in a semicontinuous system with agro-industrial residues using $S$. salmonicolor and observed that the $\mathrm{pH}$ control (4.0) throughout the bioproduction reduced the carotenoid bioproduction in relation to the process without $\mathrm{pH}$ control.

In Figure 2b, the cut of 50\% showed higher consumption of glycerol (61\%) after the second cut in $288 \mathrm{~h}$, total organic carbon (25\%) after $96 \mathrm{~h}$ of bioproduction, and of nitrogen (54\%) after the first cut in $192 \mathrm{~h}$, wherein this phase it was observed the high concentration of total carotenoid $(5346 \mu \mathrm{g} / \mathrm{L})$.

In the cut of $75 \%$ with agro-industrial residues (Figure 3) no increase in the total carotenoid production was observed when compared to the other cuts (25 and 50\%). This 
decrease may be related to the formation of secondary compounds, such as $\beta$-ionone that is formed by the carotenoid oxidation [18], and/or inhibition by the excess of nutrients.
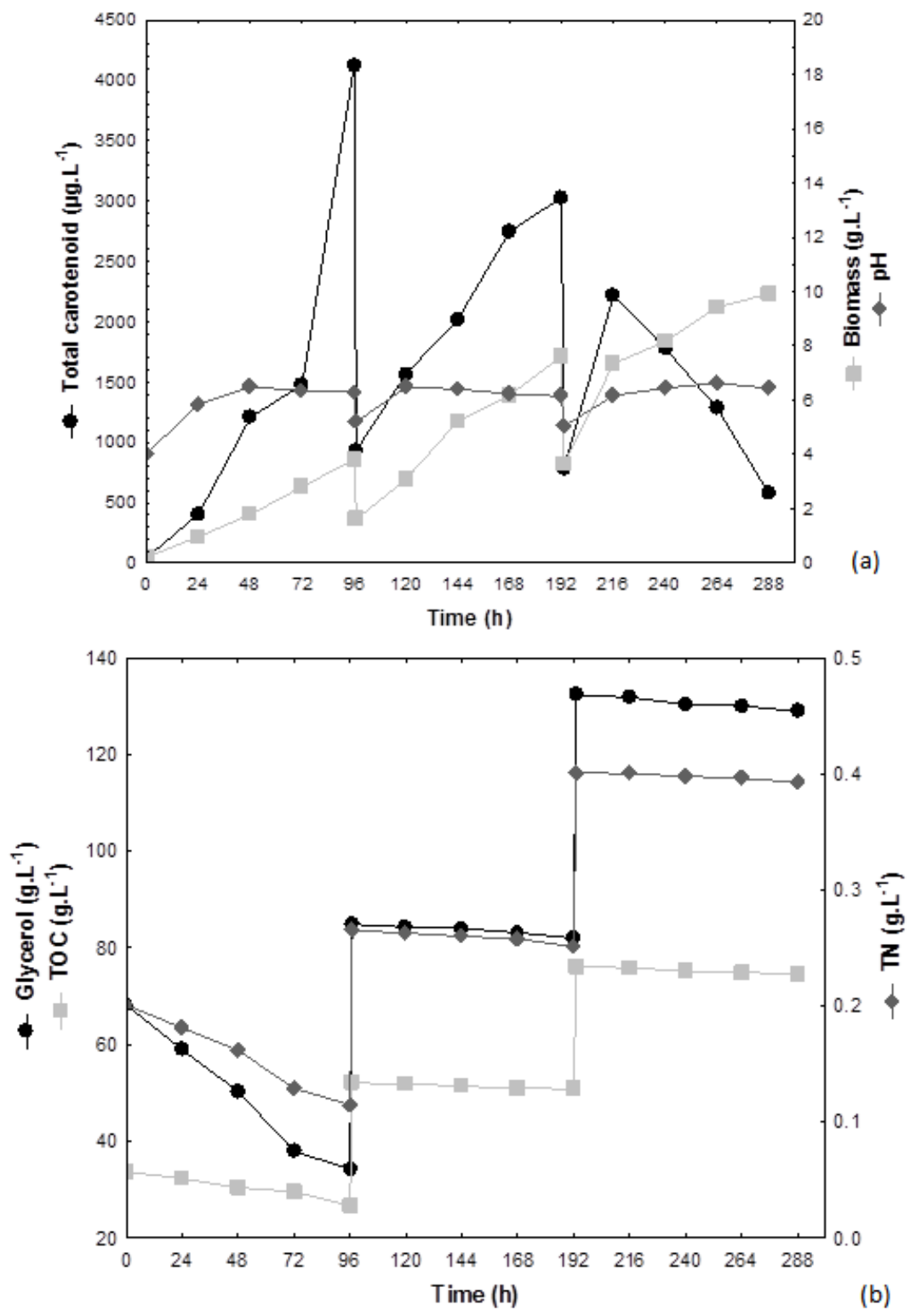

Figure 3. Kinetics of carotenoid production, biomass, and $\mathrm{pH}$ (a); substrates consumption: glycerol, TOC, and TN (b) semi-continuous process using agro-industrial residues with the cut of 75\%, every $96 \mathrm{~h}$, until $288 \mathrm{~h}$.

In the cut of $75 \%$, the volume of culture medium replaced at each beginning of the cycle was greater, that is, a greater amount of nutrients was available to the cells. However, it did not increment the cell growth (maximum $9.9 \mathrm{~g} / \mathrm{L}$ ). This can be explained by the time that the microorganism needed to adapt and grow in this new medium. Comparing the cuts of $25 \%$ and $50 \%$, it is observed a lower amount of biomass by $25 \%$. This may have occurred due to the small number of possible inhibitors and/or toxic metabolites removed from the fermented broth in the semi-continuous process. At the end of the bioproduction, there was a high concentration of total organic carbon (98.1\%), glycerol (97.4\%), and nitrogen (98\%), indicating that there was no lack of nutrients. Microelements play an important role in cell metabolism, mainly due to their requirements as cofactors for various enzymes [25]. Deficiencies or high concentrations of minerals cause significant metabolic changes [26], increasing biomass production.

Figure 4 shows the global carotenoid production in the semi-continuous process with different cuts $(25,50$, and $75 \%)$ during the cultivation. In $96 \mathrm{~h}$, it is observed similar 
productivity for both cuts (approximately $40 \mu \mathrm{g} / \mathrm{L}$. h). In the bioproduction, it is observed that the cut of 50\% maintained a superior behavior in relation to the other tests. However, after 96 $\mathrm{h}$, carotenoid productivity showed a progressive decrease. Colet et al. [21] using the $S$. salmonicolor yeast in a semi-continuous process with a cut of $50 \%$, obtained similar productivity $(41.4 \mu \mathrm{g} / \mathrm{L} . \mathrm{h})$ in $48 \mathrm{~h}$ bioproduction.

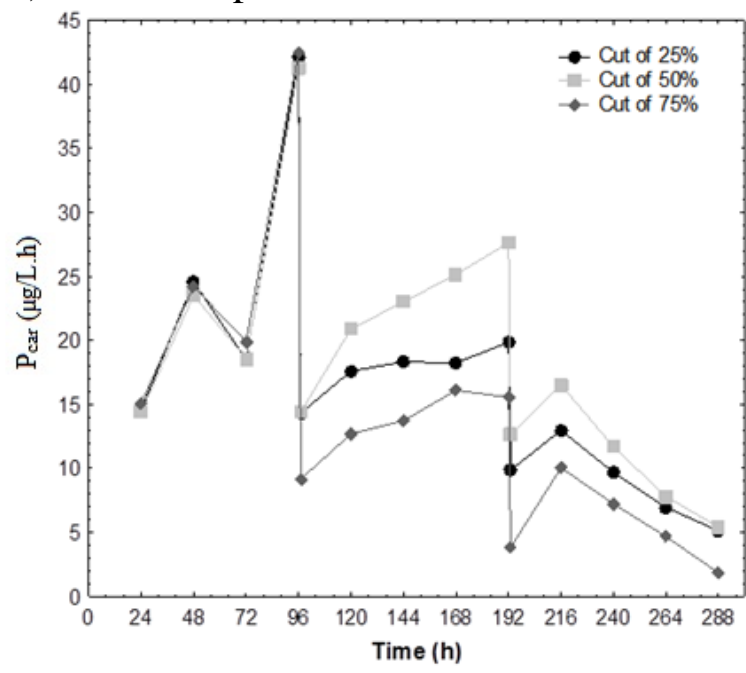

Figure 4. Global carotenoid production $\left(\mathrm{P}_{\mathrm{car}}\right)$ on the semi-continuous process using agro-industrial residues, with a cut of $25 \%, 50 \%$, and $75 \%$ at $1.5 \mathrm{vvm}, 180 \mathrm{rpm}, 25^{\circ} \mathrm{C}, \mathrm{pH}_{\text {initial }}$ of 4.0 , and $480 \mathrm{~h}$.

Table 1 shows the kinetic and stoichiometric maximum parameters obtained for $P$. rhodozyma in the semi-continuous bioproduction process.

Table 1. Kinetic and stoichiometric maximum parameters of carotenoid production in a bioreactor from tests in the semi-continuous process using agro-industrial residues.

\begin{tabular}{l|c|c|c}
\multicolumn{1}{c}{ Parameters } & $\begin{array}{c}\text { Maximum } \\
\text { obtained value }\end{array}$ & \multicolumn{1}{c}{$\begin{array}{c}\text { Cut } \\
(\%)\end{array}$} & $\begin{array}{c}\text { Time } \\
(\mathbf{h})\end{array}$ \\
$\mathrm{Y}_{\mathrm{P} / \mathrm{G}}(\mu \mathrm{g} / \mathrm{g})$ (Glycerol base) & 847 & 50 & 193 \\
\hline $\mathrm{Y}_{\mathrm{X} / \mathrm{G}}(\mathrm{g} / \mathrm{g})$ (Glycerol base) & 2.65 & 50 & 193 \\
\hline $\mathrm{Y}_{\mathrm{P} / \mathrm{C}}(\mu \mathrm{g} / \mathrm{g})$ (TOC base) & 15343 & 25 & 168 \\
\hline $\mathrm{Y}_{\mathrm{X} / \mathrm{C}}(\mathrm{g} / \mathrm{g})($ TOC base) & 31.55 & 25 & 168 \\
\hline $\mathrm{Y}_{\mathrm{P} / \mathrm{N}}(\mu \mathrm{g} / \mathrm{g})$ (Nitrogen base) & 362310 & 50 & 216 \\
\hline $\mathrm{Y}_{\mathrm{X} / \mathrm{N}}(\mathrm{g} / \mathrm{g})$ (Nitrogen base) & 1740 & 25 & 193 \\
\hline $\mathrm{Y}_{\mathrm{P} / \mathrm{X}(\mu \mathrm{g} / \mathrm{g})}$ & 1210 & 25 & 96 \\
\hline $\mathrm{P}_{\mathrm{X}}(\mathrm{g} / \mathrm{L} \cdot \mathrm{h})$ & 0.063 & 50 & 96 \\
\hline$\mu_{\mathrm{X}}\left(\mathrm{h}^{-1}\right)$ & 0.067 & 50 & 24 \\
\hline
\end{tabular}

It was observed that the maximum specific speed of growth $(\mu \max )$ of $0.067 \mathrm{~h}^{-1}$, with maximum productivity in cells $\left(\mathrm{P}_{\mathrm{x}}\right)$ of $0.063 \mathrm{~g} / \mathrm{L}$. $\mathrm{h}$, and the productivity in total carotenoids of $42.51 \mu \mathrm{g} / \mathrm{L}$. $\mathrm{h}$, using the cut of $50 \%$ in $96 \mathrm{~h}$ of bioproduction. In this way, using the semicontinuous process was possible to improve the productivity of natural pigment using agroindustrial residues. The obtained carotenoid can be used by biotechnology and food industries as additives or supplements in foods, cosmetics, pharmaceutical, among other applications.

\section{Conclusions}

The kinetic bioproduction study in a semi-continuous system, with a cut of $50 \%$, showed a high concentration of total carotenoids of $5346 \mu \mathrm{g} / \mathrm{L}(477 \mu \mathrm{g} / \mathrm{g}$ of specific carotenoids) in $192 \mathrm{~h}$. The $\mu_{\max }$ for $P$. rhodozyma Y-17268 in a semi-continuous system bioreactor was $0.067 \mathrm{~h}^{-1}$, with maximum cell productivity of $0.063 \mathrm{~g} / \mathrm{L}$. h. By the results 
obtained in the bioproduction of $P$. rhodozyma carotenoids, the semi-continuous process with a $50 \%$ cut and $192 \mathrm{~h}$ would be recommended for increasing the industrial scale, thus leading to an increase in production and consequent increase in yield. In this way, this fermentation process is very available using agro-industrial residues and is an important strategy for obtaining and recovery of pigments.

\section{Funding}

This study was financed by CAPES, Brazil [Financial Code 001].

\section{Acknowledgments}

The authors thank to National Council for Scientific and Technological Development (CNPq), Coordination for the Improvement of Higher Education Personnel (CAPES), and Research Support Foundation of the State of Rio Grande do Sul (FAPERGS).

\section{Conflicts of Interest}

The authors declare no conflict of interest.

\section{References}

1. Saini, R.K.; Keum, Y.S. Microbial platforms to produce commercially vital carotenoids at industrial scale: an updated review of critical issues. J. Ind. Microbiol. Biotechnol. 2019, 46, 657-674, https://doi.org/10.1007/s10295-018-2104-7.

2. Market Study Report, L. At 3.2\% CAGR, Natural Carotenoids Market Size is Expected to Exhibit 910 million USD by 2024 . https://www.marketdataforecast.com/market-reports/global-carotenoids-market (accessed Dec. 2019).

3. Venil, C.K.; Zakaria, Z.A.; Ahmad, W.A. Review: Bacterial pigments and their applications. Process Biochem. 2013, 48, 1065-1079, https://doi.org/10.1016/j.procbio.2013.06.006.

4. Vílchez, C.; Forján, E.; Cuaresma, M.; Bédmar, F.; Garbayo, I.; Vega, J.M. Marine carotenoids: biological functions and commercial applications. Mar. Drugs 2011, 9, 319-333, https://doi.org/10.3390/md9030319.

5. Zhang, H.; Wang, Y.; Pfeifer, B.A. Bacterial hosts for natural product production. Mol. Pharm. 2008, 5, 212-225, https://doi.org/10.1021/mp7001329.

6. dadi, P.; Barakova, N.V.; Krivoshapkina, E.F. Selected methods of extracting carotenoids, characterization, and health concerns: a review. J. Agric. Food Chem. 2018, 66, 5925-5947, https://doi.org/10.1021/acs.jafc.8b01407.

7. Hui, N.I.; Qi-He, C.; Hui, R.; Yuan-Fan, Y.; Li-Jun, L.I.; Guang-Bin, W.U.; Yang, H. U.; Guo-Qing, H.E. Studies on optimization of nitrogen sources for astaxanhin production by Phaffia rhodozyma. J. Zhejiang Univ. Sci. B 2007, 8, 365-370, https://doi.org/10.1631/jzus.2007.B0365.

8. Colet, R.; Urnau, L.; De Souza Hassemer, G.; Dias, B.B.; Zeni, J.; Rodrigues, E.; Jacques, R.A.; Di Luccio, M.; Valduga, E. Kinetic Parameters of Fed-Batch Production of Carotenoids by Sporidiobolus salmonicolor Using Low-Cost Agro-Industrial Substrates. Ind. Biotechnol. 2019, 15, 311-321. https://doi.org/10.1089/ind.2019.0015.

9. Urnau, L.; Colet, R.; Reato, P.T.; Burkert, J. F. M.; Rodrigues, E.; Gomes, R.; Jacques, R.A.; Valduga, E.; Steffens, C. Use of Low-Cost Agro-Industrial Substrate to Obtain Carotenoids from Phaffia rhodozyma in a Bioreactor. Ind. Biotechnol. 2019, 15, 25-34, https://doi.org/10.1089/ind.2018.0027.

10. Urnau, L.; Colet, R.; Soares, V.F.; Franceschi, E.; Valduga, E.; Steffens, C. Extraction of Carotenoids from Xanthophyllomyces dendrorhous using Ultrasound-Assisted and Chemical Cell Disruption Methods. Can. J. Chem. Eng. 2018, 96, 1377-1381, https://doi.org/10.1002/cjce.23046.

11. Bhatt, P.C.; Ahmad, M.; Panda, B.P. Enhanced bioaccumulation of astaxanthin in Phaffia rhodozyma by utilising low-cost agro products as fermentation substrate. Biocatal. Agric. Biotechnol. 2013, 2, 58-63, https://doi.org/10.1016/j.bcab.2012.11.002.

12. García, I.L.; López, J.A.; Dorado, M.P.; Kopsahelis, N.; Alexandri, M.; Papanikolaou, S.; Villar, M.A.; Koutinas, A.A. Evaluation of byproducts from the biodiesel industry as fermentation feedstock for poly (3hydroxybutyrate-co-3-hydroxyvalerate) production by Cupriavidus necator. Bioresour. Technol. 2013, 130, 16-22, https://doi.org/10.1016/j.biortech.2012.11.088. 
13. Saenge, C.; Cheirsilp, B.; Suksaroge, T.T.; Bourtoom, T. Potential use of oleaginous red yeast Rhodotorula glutinis for the bioconversion of crude glycerol from biodiesel plant to lipids and carotenoids. Process Biochem. 2011, 46, 210-218, https://doi.org/10.1016/j.procbio.2010.08.009.

14. Gharibzahedi, S.M T.; Razavi, S.H.; Mousavi, S.M.; Moayedi, V. High efficiency canthaxanthin production by a novel mutant isolated from Dietzia natronolimnaea HS-1using central composite design analysis. Ind. Crops Prod. 2012, 40, 345-354, https://doi.org/10.1016/j.indcrop.2012.03.030.

15. Ho, S.H.; Lu, W.B.; Chang, J.S. Photobioreactor strategies for improving the $\mathrm{CO}_{2}$ fixation efficiency of indigenous Scenedesmus obliquus CNW-N: statistical optimization of $\mathrm{CO}_{2}$ feeding, illumination, and operation mode. Bioresour. Technol. 2012, 105, 106-113, https://doi.org/10.1016/j.biortech.2011.11.091.

16. Schimidell, W.; Soares, H.M.; Etchebehere, C.; Menes, R.J.; Bertola, N.C.; Contreas, E.M. Tratamento Biológico de Águas Residuárias. Ed. Tribo da Ilha, Florianópolis, Chap. IV-2, 2007.

17. Zohri, Abdel-Naser; Ragab, S.W; Mekawi, M.I.; Mostafa, O.A.A. Comparison Between Batch, Fed-Batch, Semi-Continuous and Continuous Techniques for Bio-Ethanol Production from a Mixture of Egyptian Cane and Beet Molasses. Egypt. Sugar J. 2017, 9, 89-111.

18. Valduga, E.; Valerio, A.; Treichel, H.; Di Luccio, M.; Furigo Júnior, A. Study of the bio-production of carotenoids by Sporidiobolus salmonicolor (CBS 2636) using pre-treated agro-industrial substrates. J. Chem. Technol. Biot. 2008, 83, 1267-1274, https://doi.org/10.1002/jctb.1940.

19. Davies, B.H. Carotenoid. In: Chemistry and Biochemistry of Plants and Pigments. Goodwin, T.W. (ed.), Academic Press, New York, 1976; pp. 138-165.

20. Bailey, J.E., Ollis, D.F. Biochemical Enginnering Fundamentals. McGraw- Hill Book Company, 2ed, 1986; pp. 984.

21. Colet, R.; Urnau, L.; Bampi, J.; Zeni, J.; Dias, B.B.; Rodrigues, E.; Jacques, R.A.; Di Luccio, M.; Valduga, E. Use of low-cost agro products as substrate in semi-continuous process to obtain carotenoids by Sporidiobolus salmonicolor. Biocatal. Agric. Biotechnol. 2017, 11, 268-274, https://doi.org/10.1016/j.bcab.2017.07.015.

22. UNE-EN 14105. EN 14105. European Committee for Standardization: Management Centre. Determination of free and total glycerol and mono-, di-, triglyceride contents. Asociacion Espanola de Normalizacion y Certificacion, Madrid. 2011.

23. AOAC-Association of Official Analytical Chemists. Official methods of analysis of AOAC International. $21^{\text {st }}$ edition, 2019.

24. Valduga, E.; Valério, A.; Treichel, H.; Furigo Jr, A.; Di Luccio, M. Kinetic and Stoichiometric Parameters in the production of carotenoids by Sporidiobolus salmonicolor (CBS 2636) in synthetic and agroindustrial media. Appl. Biochem. Biotechnol. 2009, 157, 61-69, https://doi.org/10.1007/s12010-008-8383-0.

25. Stehlik-Tomas, V.; Zetic, V.G.; Stanzer, D.; Grba, S.; Vahcic, N. Zn, Cu and Mn Enrichment in S. cerevisiae. Food Technol. Biotech. 2004, 42, 115-120.

26. Schmidt, S.A.; Dillon, S.; Kolouchova, R.; Henschke, P.A.; Chambers, P.J. Impacts of variations in elemental nutrient concentration of Chardonnay musts on Saccharomyces cerevisiae fermentation kinetics and wine composition. Appl. Microbiol. Biotechnol. 2011, 90, 679-687, https://doi.org/10.1007/s00253-0113197-3. 